\title{
Epidural spinal cord compression as initial clinical presentation of an acute myeloid leukaemia: case report and literature review

\author{
Dominique N'Dri Oka ${ }^{1 *}$, Alpha Boubacar Bah², André Valentin Tokpa ${ }^{1}$ and Louis Derou
}

\begin{abstract}
Epidural localization of myeloid leukaemia is rarely reported. Spinal cord compression as an initial presentation of acute myeloid leukaemia is extremely rare. This is a report of a 17-year-old black boy who presented to emergency department with neurological symptoms of spinal cord compression. Imaging modalities showed multiple soft tissue masses in the epidural space. After surgical treatment, histopathological examination of the epidural mass showed myeloid leukaemia cells infiltration. Literature review on Medline and "scholar Google" database was done. The characteristics and management of extra-medullary leukaemia are discussed. Granulocytic sarcoma, myeloid sarcoma or chloroma with acute myeloid leukaemia should be considered as part of epidural spinal cord compression. Therefore surgery is indicated on an emergent basis.
\end{abstract}

Keywords: Spinal cord compression, Initial epidural localization, Acute myeloid leukaemia

\section{Background}

Acute myeloid leukaemia corresponds to malignant monoclonal proliferation of medullary blastic myeloid cells with an interrupted differentiation [1]. Clinically acute myeloid leukaemia will result in adenopathy and hepatosplenic syndrome associated with bone marrow failure syndrome. Extra nodal involvement is rare and mostly made of frequently observed forms of lymphoblastic leukemia in children. These attacks represent 2 to $8 \%$ of acute myeloid leukaemia. Epidural localization is unusual and is a rare cause of spinal cord compression. Spinal cord compression as an initial presentation of acute myeloid leukaemia is extremely rare. In this study, we did not consider Spinal cord compression as the initial presentation of acute biphenotypic leukaemia [2]. The authors reported a case of acute myeloid leukaemia revealed by thoracic spinal cord compression. Literature review follows the case report.

\section{Clinical case}

A 17-year -old A black patient with no known significant medical history, complained of a 3-week history of

\footnotetext{
* Correspondence: ndriokad@gmail.com

${ }^{1}$ Department of Neurosurgery, Teaching Hospital of Yopougon in Abidjan Ivory Coast, 21 BP 632 Abidjan, Côte d'Ivoire

Full list of author information is available at the end of the article
}

inter-scapular back pain progressively exacerbating with insomnia associated with paraesthesia, hypoesthesia of the lower limbs and trunk. The rapidly worsening deficit led to emergent Neurosurgery consultation. Neurological examination found an almost paraplegic patient with increased deep tendon reflexes, a bilateral Babinski, a distended bladder, hypoesthesia and dysesthesia with at T10 sensitive level. Further clinical examination found no evidence of lymphadenopathy or hepatosplenomegaly. The diagnosis of spinal cord compression was made and a spinal CT scan showed an extensive epidural mass at T4-T9. MRI confirmed the presence of a thoracic epidural mass posterior to the spinal cord between T4 and T9 (Fig. 1a, b, c, d, e, f). The MR imaging showed hypointense lesion on T1 weighted sequence, isointense on T2 weighted sequence and enhanced on T1 with gadolinium. There was a distinct line of dura demarcation between the tumor mass and the spinal cord.

Full blood count revealed leucocytosis with a importantly increased white blood cell count $200,000 / \mathrm{mm}^{3}$, with $77 \%$ blasts, haemoglobin: $10.7 \mathrm{~g} / \mathrm{dL}^{-1 ;}$ platelet count: $102 \times 10^{9} \mathrm{~L}^{-1}$. The myelogram diagnosis was acute myelogenous leukaemia. Histologically the tumor is composed of immature cells. There are some immature eosinophile and neutrophile. Cytogenetic evaluation 

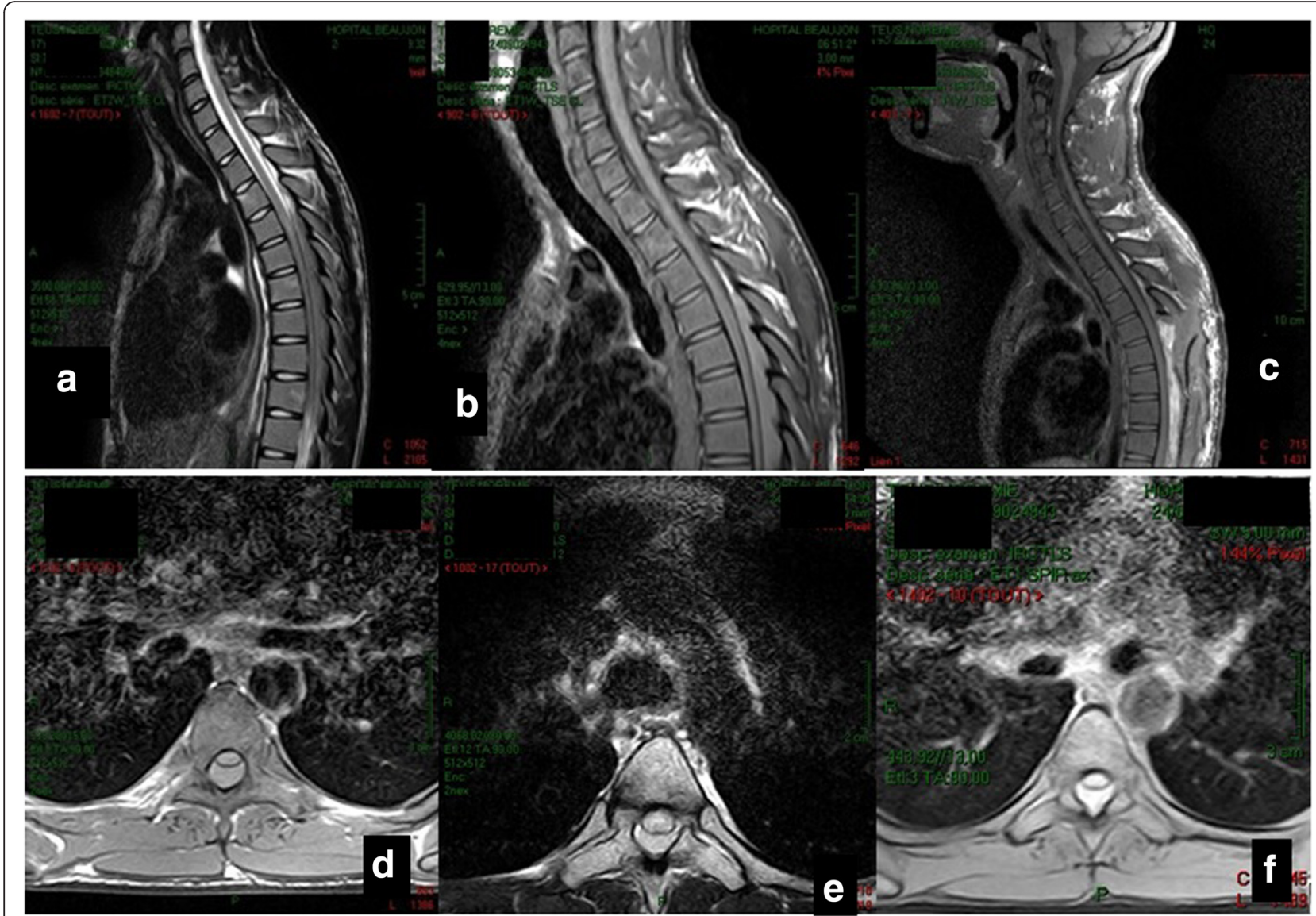

Fig. 1 Spine MRI showing spinal cord compression at T4-T9 level by posterior epidural mass. a Sagittal view showing a T4T9 posterior mass which is isointense on T2 weighted sequence. $\mathbf{b}$ Sagittal view T1 sequence showing a hypointense T4T9 posterior lésion well demarcated from the dura. c Sagittal view showing a contrast enhancement of the T4-T9 lesion. d Axial view: The lesion is hypointense on T1 weighted sequence. e Axial view: The lesion is isointense on T2 sequence at the level of T5. f Axial view showing the enhancing lesion at the level of T5 wth a good demarcation from the dura

could not be done. Additional blood test did not find bleeding disorders or ion anomaly. Given the severity of the neurological picture and predicted rapid deterioration, a laminectomy from $\mathrm{T} 4$ to $\mathrm{T} 10$ was performed in emergency and found that the posterior epidural space was occupied by greyish, haemorrhagic tumour tissue, completely separated from the dura and pushes forwards. A macroscopically complete tumour resection was performed. Haemostasis was difficult. Histopathological examination of the tumour mass was favourable to leukemic blast cells. It was type 2 leukemia (Fig. 2). Advanced treatment of acute
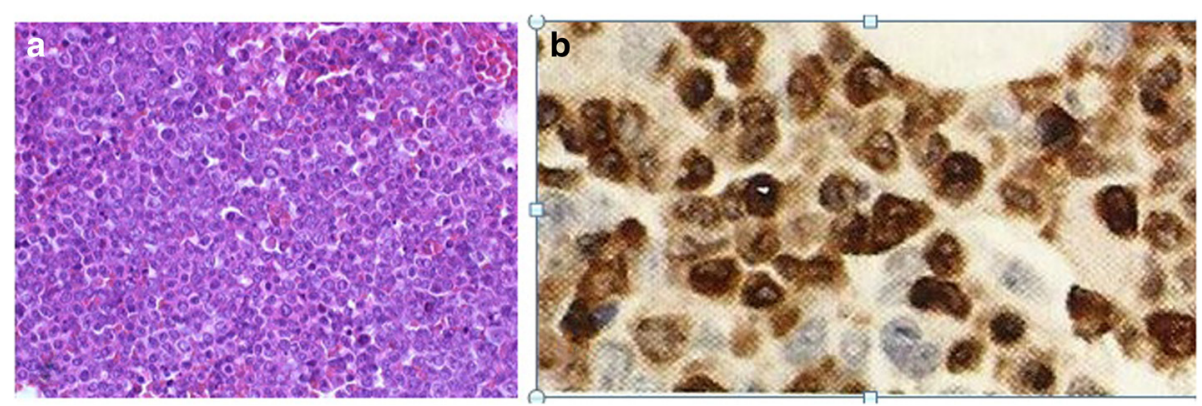

Fig. 2 HE X 100: Tumor proliferation with blasts exhibiting cytonuclear atypia (a). Immunohistochemistry X 200: Nuclear expression of antibodies anti myeloperoxidase (MPO) by the majority of undifferentiated blasts (b) 
Table 1 Literature review from 2005 to 2015. characterization of acute myeloid leukemia associated to spinal cord compression

\begin{tabular}{|c|c|c|c|c|c|c|c|c|c|}
\hline $\mathrm{Nb}$ & References & $\begin{array}{l}\text { Sex/age } \\
\text { (years) }\end{array}$ & Cytogenetic & $\begin{array}{l}\text { Histology and } \\
\text { immunohistochemistry }\end{array}$ & Localization & signs & MR Imaging & Laboratory findings & $\begin{array}{l}\text { Delay and diagnosis } \\
\text { treatement and outcome }\end{array}$ \\
\hline 1 & $\begin{array}{l}\text { Meltzer et al. } \\
2005 \text { [3] }\end{array}$ & $M / 10$ & - & $\begin{array}{l}\text {-Myeloblastic Acute myeloid } \\
\text { leukemia-Chloroma }\end{array}$ & T2-T6 & $\begin{array}{l}\text {-Midback pain-weight } \\
\text { loss-decreased sensation } \\
\text { to vibration and light } \\
\text { touch over the left leg } \\
\text {-decreased sensation to } \\
\text { pain and temperature in } \\
\text { the right leg }\end{array}$ & $\begin{array}{l}\text {-paravertebral lesions } \\
\text { with spinal-posterior } \\
\text { epidural and } \\
\text { prevertebral mass }\end{array}$ & $\begin{array}{l}\text { WBC } 12,800 / \mathrm{mm}^{3}, \mathrm{HB} 9.4 \mathrm{~g} / \\
\mathrm{dl} \text {, platelet } 74,800 / \mathrm{mm}^{3} .- \\
\text { lactate dehydrogenase was } \\
570 \text { IU/l,-immature cells }\end{array}$ & $\begin{array}{l}-3 \text { weeks-Laminectomie } \\
+ \text { Chemotherapy }+ \\
\text { spinal radiation-Total } \\
\text { Neurological } \\
\text { improvement after } 6 \\
\text { month-well more than } \\
18 \text { months of therapy }\end{array}$ \\
\hline 2 & $\begin{array}{l}\text { Ghalaut et al. } \\
\text { 2005. [4] }\end{array}$ & $23 / \mathrm{M}$ & - & $\begin{array}{l}\text { Granulocytic sarcoma due } \\
\text { to acute myeloid leukemia }\end{array}$ & T4-T6 & $\begin{array}{l}\text {-Backache-numbness of } \\
\text { bilateral legs-sensory } \\
\text { loss up to mid thoracic } \\
\text { region anemia }\end{array}$ & $\begin{array}{l}\text {-Epidural mass } \\
\text { extending from T4-T6 } \\
\text { with marrow signal } \\
\text { alteration involving } \\
\mathrm{T} 1 \text { and } \mathrm{T} 5 \text { to } \mathrm{T} 7\end{array}$ & - & $\begin{array}{l}\text { - surgical excision + } \\
\text { chemotherapy } \\
\text {-neurological } \\
\text { improvement }\end{array}$ \\
\hline \multirow[t]{2}{*}{3} & \multirow[t]{2}{*}{$\begin{array}{l}\text { Amalraj et al. } \\
2009[5]\end{array}$} & \multirow[t]{2}{*}{$14 / \mathrm{M}$} & \multirow[t]{2}{*}{-} & \multirow[t]{2}{*}{$\begin{array}{l}\text { Granulocytic sarcoma } \\
\text { promyelocytic leukemia } \\
\text { AML M3 }\end{array}$} & \multirow[t]{2}{*}{ T3-T10 } & \multirow{2}{*}{$\begin{array}{l}\text {-Acute paraplegia } \\
\text {-weakness of both lower } \\
\text { limbs-numbness of both } \\
\text { lower limbs-back pain } \\
\text { for the last-bladder } \\
\text { symptoms }\end{array}$} & \multirow[t]{2}{*}{$\begin{array}{l}\text { hypointense in } \mathrm{T} 1 \\
\text { hyperintense in } \mathrm{T} 2 \\
\text { dorsally compressing } \\
\text { the spinal cord }\end{array}$} & $\begin{array}{l}\text { Hemoglobin } 13 \text { gm\%, total } \\
\text { count 8,400, polymorph } \\
60 \% \text {, and lymph } 40 \% \text {, } \\
\text { with high erythrocyte. }\end{array}$ & \multirow[t]{2}{*}{$\begin{array}{l}\text {-paraplegia improved } \\
\text { with radiotherapy and } \\
\text { chemotherapy }\end{array}$} \\
\hline & & & & & & & & $\begin{array}{l}\text { RBC mild hypochromic } \\
\text { microcytic, WBC count } \\
\text { normal predominantly blast } \\
\text { cells with high nuclear } \\
\text { cytoplasmic ratio, moderate } \\
\text { cytoplasm, hyperchromatic } \\
\text { nuclei with multiple nucleoli, } \\
\text { platelet count decreased. }\end{array}$ & \\
\hline \multirow[t]{4}{*}{4} & \multirow{4}{*}{$\begin{array}{l}\text { Olcay et al. } \\
2009[6]\end{array}$} & \multirow[t]{4}{*}{$M / 12$} & \multirow{4}{*}{$\begin{array}{l}\text { Cytogenetic } \\
\text { evaluation could } \\
\text { not be done. }\end{array}$} & acute myeloblastic leukemia & \multirow{4}{*}{$\begin{array}{l}\text { Lumbar } \\
\text { (L3) -Conus } \\
\text { medullaris- } \\
\text { left } \\
\text { maxillary } \\
\text { mass }\end{array}$} & \multirow{4}{*}{$\begin{array}{l}\text {-Conus medullaris } \\
\text { syndrome }\end{array}$} & \multirow{4}{*}{$\begin{array}{l}\text { Cauda equine nerve } \\
\text { roots were thickened } \\
\text { and clumped in the left } \\
\text { anterolateral side of } \\
\text { the spinal canal. }\end{array}$} & $\mathrm{Hb}: 8 \mathrm{~g} / \mathrm{dL}$ & \multirow{4}{*}{$\begin{array}{l}\text {-Chemotherapy + triple } \\
\text { intratecal therapy- } \\
\text { Radiotherapy-Symptom } \\
\text { partially resolved died } \\
\text { because of pneumonia } \\
\text { and disseminated } \\
\text { intravascular coagulation }\end{array}$} \\
\hline & & & & CD45:95.15 \%, CD15: $35.56 \%$, & & & & WBC : $7.4 \times 109 / \mathrm{mm}^{3}$ & \\
\hline & & & & $\begin{array}{l}\text { CD33:77.57 \%, CD117:79.3 \%, } \\
\text { CD34:43.38 \%, CD13:29.32 \%. }\end{array}$ & & & & Thrombocyte: $60.10^{9} / \mathrm{mm}^{3}$ & \\
\hline & & & & $\begin{array}{l}\text { HLA-DR:86, } 4 \% \text {, } \\
\text { CDw65:23.9\%, CD19:49.54 \% } \\
\text { CD20:21.65 \%, CD14:3.14 \%. }\end{array}$ & & & & $\begin{array}{l}\text { Lactate dehydrogenase: } \\
691 \text { U/l }\end{array}$ & \\
\hline \multirow[t]{4}{*}{5} & \multirow[t]{4}{*}{$\begin{array}{l}\text { Yin et al. } \\
2010[7]\end{array}$} & \multirow[t]{4}{*}{$28 / \mathrm{M}$} & \multirow[t]{4}{*}{-} & $\begin{array}{l}\text { myeloid sarcoma with acute } \\
\text { myeloid leukemia }\end{array}$ & \multirow[t]{4}{*}{$\mathrm{T} 12-\mathrm{L} 1$} & \multirow{4}{*}{$\begin{array}{l}\text {-low back pain- } \\
\text { numbness of his legs- } \\
\text { bladder-incontinence- } \\
\text { hypoesthesia below } \\
\text { T12 paraparesis }\end{array}$} & \multirow[t]{4}{*}{$\begin{array}{l}\text {-Posterior epidural } \\
\text { mass T12-L1 }\end{array}$} & \multirow{4}{*}{$\begin{array}{l}\text { White blood cell } 3,900 / \\
\mathrm{mm}^{3} \text { - hemoglobin : } 11.0 \\
\mathrm{~g} / \mathrm{dL} \text {-hematocrit of } 38.2 \% \text {. }\end{array}$} & $\begin{array}{l}\text { High-dose } \\
\text { methylprednisolone }\end{array}$ \\
\hline & & & & \multirow[t]{3}{*}{$\begin{array}{l}\text { CD68, CD45, CD43, CD117 } \\
\text { and lysozyme but not of } \\
\text { MPO, CD20 }\end{array}$} & & & & & $\begin{array}{l}\text {-Decompression with } \\
\text { T12-L1 laminectomy } \\
\text { and tumor resection. }\end{array}$ \\
\hline & & & & & & & & & $\begin{array}{l}\text { Paraparesis } \\
\text { Improvement }\end{array}$ \\
\hline & & & & & & & & & $\begin{array}{l}\text { - anti-AML therapy, but } \\
\text { died of sepsis }\end{array}$ \\
\hline \multirow[t]{2}{*}{7} & \multirow{2}{*}{$\begin{array}{l}\text { Bittencourt } \\
\text { et al. } 2011[8]\end{array}$} & \multirow[t]{2}{*}{$53 / \mathrm{M}$} & \multirow{2}{*}{$\begin{array}{l}\mathrm{t}(15 ; 17)(\mathrm{q} 22 \mathrm{q} 21) \\
\text { abnormality }\end{array}$} & \multirow{2}{*}{$\begin{array}{l}\text {-Acute promyelocytic } \\
\text { leukemia presenting } \\
\text { as extradural mass-PCR }\end{array}$} & \multirow[t]{2}{*}{ T6-T8 } & \multirow{2}{*}{$\begin{array}{l}\text {-Progressive fatigue, } \\
\text { pain legs weakness } \\
\text { Paraparesis- Gingival }\end{array}$} & \multirow{2}{*}{$\begin{array}{l}\text { Posterolateral } \\
\text { extradural mass from }\end{array}$} & $\mathrm{Hb}: 10,6 \mathrm{~g} / \mathrm{dl}^{-1}$ & \multirow{2}{*}{$\begin{array}{l}\text { delais4 months/ } \\
\text { chemotherapy } \\
\text { (daunorubicin) + }\end{array}$} \\
\hline & & & & & & & & WBC: $7,5.10^{9} / L^{-1}$ & \\
\hline
\end{tabular}


Table 1 Literature review from 2005 to 2015. characterization of acute myeloid leukemia associated to spinal cord compression (Continued)

\begin{tabular}{|c|c|c|c|c|c|c|c|c|c|}
\hline & & & & for the PML-RARa gene & & hemorrhage, & T6-T8 with medullar & Platelet:12.109//-1 & radiotherapy/Evolution: \\
\hline & & & & was positive & & hepatomegaly & compression & Fibrinogen:1.4 g/L-1 & $\begin{array}{l}\text { no neurologic } \\
\text { improvement }+\end{array}$ \\
\hline & & & & & & & & INR: 1.86 (N:0,8-1,2) & died of sepsis \\
\hline & & & & & & & & $\begin{array}{l}\text { Uric acid and lactate } \\
\text { dehydrogenase were } \\
\text { both elevated }\end{array}$ & \\
\hline 8 & Kyaw et al. & $26 / M$ & - & -Myeloid sarcoma: acute & T2-T4 and & Progressive back pain & Multiple hyperintense & $\mathrm{Hb}: 10,7 \mathrm{~g} / \mathrm{dL}^{-1}$ & -Radiotherapy- \\
\hline & 2012 [9] & & & $\begin{array}{l}\text { promyelocytic leukemia- } \\
\text { CD33, CD117, CD64, CD34 }\end{array}$ & T12 - L2 & $\begin{array}{l}\text { and bilateral leg } \\
\text { weakness: -paraparesis }\end{array}$ & $\begin{array}{l}\mathrm{T} 12, \mathrm{~L} 1, \mathrm{~L} 2, \mathrm{~L} 4 \text { and } \mathrm{L} 5 \\
\text { vertebral bodies and }\end{array}$ & $W B C: 2,8 \cdot 10^{9} / L^{-1}$ & $\begin{array}{l}\text { Chemotherapy: } \\
\text { retinoic acid + ida }\end{array}$ \\
\hline & & & & and cytoplasmic MPO were & & Loss of pain and & sacrum & Platelet : $102.10^{9} / \mathrm{L}^{-1}$ & rubicin-Neurological \\
\hline & & & & $\begin{array}{l}\text { presented Reverse } \\
\text { transcriptase-polymerase } \\
\text { chain reaction showed BCR1- } \\
\text { type PML-RARa fusion copies }\end{array}$ & & & $\begin{array}{l}\text { Intraspinal extradural } \\
\text { masses } L 4 \text { and } L 5 \\
\text { vertebral bodies and } \\
\text { sacrum }\end{array}$ & & $\begin{array}{l}\text { Improvement - } \\
\text { Good remission }\end{array}$ \\
\hline & & & & & & & $\begin{array}{l}\text { Intraspinal extradural } \\
\text { masses located fromT2 } \\
\text { toT4 and T12 to L2. }\end{array}$ & & \\
\hline 9 & $\begin{array}{l}\text { Ben et al. } \\
2013 \text { [10] }\end{array}$ & $21 / \mathrm{M}$ & $\begin{array}{l}\text { karyotype: } 46 \text {, } \\
X Y, t(8,21)\end{array}$ & $\begin{array}{l}\text { chloromaCD3, } \\
\text { CD20 = --positive for }\end{array}$ & $\begin{array}{l}\mathrm{T} 4 / \mathrm{T} 7, \mathrm{~T} 1- \\
\mathrm{T} 2\end{array}$ & $\begin{array}{l}\text { Progressive paraplegia. } \\
\text { urinary retention }\end{array}$ & $\begin{array}{l}\text { intermediate in } \mathrm{T} 1 \text {, } \\
\text { hyperintense in } \mathrm{T} 2\end{array}$ & $\begin{array}{l}\text { hemoglobin } 8 \mathrm{~g} / \mathrm{dL}^{-1} \text {, white } \\
\text { blood cell count } 3100 / \mathrm{mm}^{3} \text {, }\end{array}$ & $\begin{array}{l}\text { laminectomy + tumour } \\
\text { was totally removed }\end{array}$ \\
\hline & & & $\begin{array}{l}(q 22 ; q 22) / \\
46, X Y\end{array}$ & $\begin{array}{l}\text { myeloperoxidaseacute } \\
\text { myeloblastic leukaemia } \\
\text { (AML) of the French- } \\
\text { American-British } \\
\text { M2 subtype }\end{array}$ & & & & $\begin{array}{l}\text { platelet count } 44000 / \mathrm{mm} \\
\text { and } 3 \% \text { neutrophils, } 44 \% \\
\text { lymphocytes and } 44 \% \text {. }\end{array}$ & $\begin{array}{l}\text {-rubidomycine }\left(45 \mathrm{mg} / \mathrm{m}^{2}\right. \\
\text { daily for } 3 \text { days) and } \\
\text { cytosine arabinoside } \\
\left(200 \mathrm{mg} / \mathrm{m}^{2} \text { continuous }\right. \\
\text { infusion for } 7 \text { days). } \\
\text {-improvement } \\
\text { paraplegia- complete } \\
\text { remission }\end{array}$ \\
\hline 10 & $\begin{array}{l}\text { Krishnamurthy } \\
\text { et al. } 2014 \text { [11] }\end{array}$ & $16 / M$ & - & $\begin{array}{l}\text { Granulocytic sarcoma } \\
\text { associated with leukaemia,- } \\
\text { acute myeloblastic leukaemia } \\
\text { (AML) of the French- } \\
\text { American-British M2 } \\
\text { subtype.-subleukemic } \\
\text { leukemia }\end{array}$ & & $\begin{array}{l}\text { Low backaches follow } \\
\text { proptosis, spinal cord } \\
\text { causing significant } \\
\text { compression of the } \\
\text { spinal cord. }\end{array}$ & $\begin{array}{l}\text { Multiple midline } \\
\text { fusiform extra-dural } \\
\text { masses which are } \\
\text { iso- intense to cord on } \\
\text { T1W images seen } \\
\text { extending from C3- } \\
\text { C7, D3-D5, D11- } \\
\text { D12 \& S1-S2 are } \\
\text { seen posteriorly }\end{array}$ & 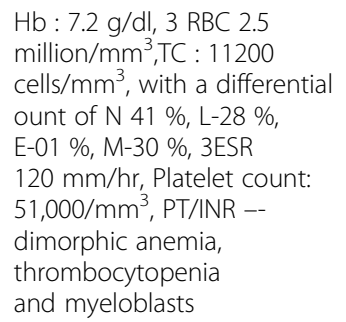 & $\begin{array}{l}\text {-radiotherapy and } \\
\text { chemotherapy }\end{array}$ \\
\hline 11 & Present case. & $17 / \mathrm{M}$ & $\begin{array}{l}\text {-Cytogenetic } \\
\text { evaluation could } \\
\text { not be done. }\end{array}$ & $\begin{array}{l}\text {-Myeloid leukemia- } \\
\text { type } 2 \text { leukemia }\end{array}$ & T4T9 & Acute paraplegia & $\begin{array}{l}\text { hypointense lesion on } \\
\text { T1 weighted sequence } \\
\text { isointense T2 weighted } \\
\text { sequence enhanced on } \\
\text { T1 with gadolinium. } \\
\text { (epidural mass } \\
\text { (hyperintense) }\end{array}$ & $\begin{array}{l}\text { blood count revealed } \\
\text { leucocytosis with a major } \\
\text { white blood cell count } \\
200,000 / \mathrm{mm}^{3} \text {, with } 77 \% \\
\text { blasts, hemoglobin: } \\
10.9 \mathrm{~g} \mathrm{dl} \text {; platelet count: } \\
106 \times 10^{9} \mathrm{~L}^{-1}\end{array}$ & $\begin{array}{l}\text {-Chemotherapy- } \\
\text { Died one week } \\
\text { after diagnosis }\end{array}$ \\
\hline
\end{tabular}


myeloid leukaemia was indicated. But the patient died a week after the diagnosis of spinal cord compression because of sepsis.

\section{Discussion}

The spinal cord compression revealing acute myeloid leukaemia is unusual. Nine cases have been reported from 2005 to 2015 [3-11] (Table 1). It often appears like a solid tumour known as granulocytic sarcoma or myeloid, or also chloroma as seen in our patient [12]. It corresponds to the migration outside of the bone marrow of myeloid cells that proliferate on their own [1]. The first case was described in 1811 by Burns in 1893 and Dock who reported its association with leukaemia [13, 14]. It is reported in 3.1 to $9.1 \%$ of patients with acute myeloid leukaemia [15]. We found ten cases from 2005 to 2015 which were reported in literature. In those cases epidural space was occupied by granulocyt sarcoma [3-9 11, 15]. Surgically excision of the tumour appeared to be the first treatment option in these cases. Granulocytic sarcoma is frequently diagnosed simultaneously with or after the start of an acute myeloid leukaemia or may be the initial sign of a relapse in a patient in remission [3-9, 11, 15]. In non-leukemic patients, myeloid granulocytic sarcoma usually precedes acute myeloid leukaemia [16]. In 87 to $88 \%$ of patients without hematologic abnormalities at diagnosis, acute myeloid leukaemia develops in the 10.5 to 11 following months [17]. Myeloid sarcoma may occur in all tissues but they are frequently localized on the skin, bone, soft tissues of the head and neck (especially on the orbit) and adenopathies [18]. Spinal localization and especially epidural is rare. Thoracic localization is the most frequent spinal localization followed by lumbar and sacral localizations. Clinical signs are in most cases made of spinal cord compression. Sometimes they involve isolated rachialgia [3-9, 11, 15]. MRI is the best choice for neuroimaging examination to show epidural tumour lesions. It is also the best neuroimaging examination $[3-9,11,15]$ to show the epidural tumour lesions without being specific. Granulocytic sarcoma is isointense in T1 and T2 with in general a contrast enhancement $[3-9,11,15]$. The therapeutic strategy of this myeloid sarcoma is based on chemotherapy, radiation therapy, surgical decompression and bone marrow transplantation and any combination of these methods $[3-9,11,15]$. 1n cases of granulocytic sarcoma in particular by acute myeloid leukaemia with neurological signs, priority should be given to chemotherapy and/or radiation therapy rather than surgery. In our patient the diagnosis of acute myeloid leukaemia was made from full blood count after surgery. Surgery was only justified by the acuteness and quickly worsening neurological disorders. Despite some cases of more or less complete neurological recovery with a variable remission, most patients present with neurological sequellae and die from haematological complications dominated by sepsis.

\section{Conclusion}

This case associated with the literature review has shown that granulocytic sarcoma with acute myeloid leukaemia should be considered as part of epidural spinal cord compression it might be the initial sign of epidural spinal cord compression . Therefore surgery is indicated in emergency. Chemotherapy and radiotherapy are secondly introduced according to the diagnosis.

\section{Competing interests \\ The authors declare that they have no competing interests.}

\section{Authors' contributions}

DNO has performed the surgery, evaluated the patient, and drafted and revised the manuscript. ABB assisted the surgeon at the operation room, grammatically reviewed the manuscript and participated to the discussion. AVT evaluated the patient, carried out the literature review. LD evaluated the patient, carried out the literature review. All authors read and approved the final manuscript.

\section{Acknowledgements}

We thank Sir Djo Bl doctor Alban Mbende Professor koffi Gustave in haematology department in yopougon and Dr Doukouré Brahim Histopatology department for their help.

\section{Author details}

${ }^{1}$ Department of Neurosurgery, Teaching Hospital of Yopougon in Abidjan Ivory Coast, 21 BP 632 Abidjan, Côte d'Ivoire. ²Department of Neurosurgery, Teaching Hospital of Conakry, Conakry, Guinea.

Received: 11 September 2015 Accepted: 20 November 2015 Published online: 18 January 2016

\section{References}

1. Pileri SA, Ascani S, Cox MC, Campidelli C, Bacci F, Paccioli M, et al. Myeloid sarcoma. Clinico-pathologic, phenotypic and cytogenetic analysis of 92 adult patients. Leukemia. 2007;21:340-50.

2. Dimou J, Jithoo R, Tsui A, Morokoff AP. Spinal cord compression as the initial presentation of acute biphenotypic leukaemia. J Clin Neurosci. 2009; 16(12):1696-8.

3. Meltzer JA, Jubinsky PT. Acute myeloid leukemia presenting as spinal cord compression. Pediatr Emerg Care. 2005;21(10):670-2.

4. Ghalaut PS, Jindal S, Jeevan O. Granulocytic sarcoma as initial presentation of acute myeloid leukaemia. J Assoc Physicians India. 2005;53:828-30.

5. Amalraj P, Syamlal S. Unusual case of paraplegia. Ann Indian Acad Neurol. 2009;12(3):188-90.

6. Olcay L, Aribaş BK, Gökçe M. A patient with acute myeloblastic leukemia who presented with conus medullaris syndrome and review of the literature. J Pediatr Hematol Oncol. 2009;31(6):440-7.

7. Yin Q, Zhou YY, Chen D, Li WL. Different outcome of myeloid sarcoma with spinal cord compression preceding acute myeloid leukemia: report of two cases and review of literature. Chin J Cancer Res. 2010;22(2):156-62.

8. Bittencourt $H$, Teixeira Junior AL, Glória AB, Ribeiro AF, Fagundes EM. Acute promyelocytic leukemia presenting as an extradural mass. Rev Bras Hematol Hemoter. 2011;33(6):478-80.

9. Kyaw TZ, Maniam JAS, Bee PC, Cin EFM, Nadarajan VS, Shanmugam H, et al. Myeloid sarcoma: an unusual presentation of acute promyelocytic leukemia causing spinal cord compression. Turk J Hematol. 2012;29:278-82.

10. Ben FW, Zahra K, Ben HI, Hadhri R, Khelif A. Paraplegia due to chloroma as the initial presenting feature of acute myeloid leukaemia. Pan Arab J Neurosurg. 2013;17(1):4.

11. Krishnamurthy VG, Narendra SS, Bhagwat KA, Shashikala P, Prashanth S, Khanpur R. Granulocyte sarcoma presenting as acute paraplegia and Proptosis. J Pub Health Med Res. 2014;2(2):52-4.

12. Frohna BJ, Quint DJ. Granulocytic sarcoma (chloroma) causing spinal cord compression. Neuroradiology. 1993;35:509-11.

13. Dock G. Chloroma and its relation to leukemia. Am J Med Sci. 1893;106:152-85

14. Burns EW. Chloroma and paraplegia: report of a case. N Z Med J. 1963;62:422-5. 
15. Eser $B$, Cetin M, Kontas O, Er AUO, Coskun HS, Altinbas MR. Facial nerve paralysis and paraplegia as presenting symptoms of acute myeloid leukaemia. Jpn J Clin Oncol. 2001;31(2):86-8.

16. Serefhanoglu S, Goker H, Aksu S, Buyukasik Y, Sayinalp N, Haznedaroglu IC, et al. Spinal myeloid sarcoma in two non-leukemic patients. Intern Med. 2010:49(22):2493-7.

17. Neiman RS, Barcos M, Berard C, Bonner H, Mann R, Rydell RE, et al. Granulocytic sarcoma: a clinicopathologic study of 61 biopsied cases. Cancer. 1981;48:1426-37.

18. Balleari E, Panarello S, Capello E, Grosso M, Passalia C, Pitto P, et al. Granulocytic sarcoma : an unusual cause of spinal compression. Int J Clin Oncol. 2007;12:234-7.

Submit your next manuscript to BioMed Central and we will help you at every step:

- We accept pre-submission inquiries

- Our selector tool helps you to find the most relevant journal

- We provide round the clock customer support

- Convenient online submission

- Thorough peer review

- Inclusion in PubMed and all major indexing services

- Maximum visibility for your research

Submit your manuscript at www.biomedcentral.com/submit
Biomed Central 